\title{
Modelling Marine Sediment Biogeochemistry: Current Knowledge Gaps, Challenges, and Some Methodological Advice for Advancement
}

OPEN ACCESS

Edited by:

Christian Grenz,

UMR7294 Institut Méditerranéen

d'Océanographie (MIO), France

Reviewed by:

Karen Wild-Allen,

CSIRO Oceans and Atmopshere,

Australia

Nafsika Papageorgiou,

Hellenic Centre for Marine Research,

Greece

${ }^{*}$ Correspondence: Gennadi Lessin gle@pml.ac.uk

Specialty section

This article was submitted to Marine Ecosystem Ecology,

a section of the journal

Frontiers in Marine Science

Received: 25 October 2017

Accepted: 16 January 2018

Published: 02 February 2018

Citation:

Lessin G, Artioli Y, Almroth-Rosell E, Blackford JC, Dale AW, Glud RN, Middelburg JJ, Pastres R, Queirós AM, Rabouille C, Regnier $P$ Soetaert K, Solidoro C, Stephens N and Yakushev E (2018) Modelling Marine Sediment Biogeochemistry: Current Knowledge Gaps, Challenges, and Some Methodological Advice for Advancement. Front. Mar. Sci. 5:19.

doi: 10.3389/fmars.2018.00019
Gennadi Lessin ${ }^{1 *}$, Yuri Artioli ${ }^{1}$, Elin Almroth-Rosell ${ }^{2}$, Jerry C. Blackford ${ }^{1}$, Andrew W. Dale ${ }^{3}$, Ronnie N. Glud ${ }^{4,5,6}$, Jack J. Middelburg ${ }^{7}$, Roberto Pastres ${ }^{8}$, Ana M. Queirós ${ }^{1}$, Christophe Rabouille ${ }^{9}$, Pierre Regnier ${ }^{10}$, Karline Soetaert ${ }^{11}$, Cosimo Solidoro ${ }^{12}$, Nicholas Stephens ${ }^{13}$ and Evgeniy Yakushev ${ }^{14,15}$

${ }^{1}$ Plymouth Marine Laboratory, Plymouth, United Kingdom, ${ }^{2}$ Swedish Meteorological and Hydrological Institute, Oceanographic Research, Norrköping, Sweden, ${ }^{3}$ GEOMAR Helmholtz Centre for Ocean Research Kiel, Kiel, Germany, ${ }^{4}$ Scottish Association for Marine Sciences, Scottish Marine Institute, Oban, United Kingdom, ${ }^{5}$ Nordcee, Department of Biology, University of Southern Denmark, Odense, Denmark, ${ }^{6}$ Department of Ocean and Environmental Sciences, Tokyo University of Marine Science and Technology, Tokyo, Japan, ${ }^{7}$ Department of Earth Sciences, Faculty of Geosciences, Utrecht University, Utrecht, Netherlands, ${ }^{8}$ Department of Environmental Sciences, Informatics and Statistics (DAIS), University of Ca' Foscari, Venice, Italy, ${ }^{\circ}$ Laboratoire des Sciences du Climat et de l'Environnement, LSCE/IPSL, CEA-Centre National de la Recherche Scientifique-UVSQ-Université Paris Saclay, Gif-sur-Yvette, France, ${ }^{10}$ Department Geosciences, Environment and Society, Université Libre de Bruxelles, Brussels, Belgium, ${ }^{11}$ Department of Ecosystems Studies, Royal Netherlands Institute for Sea Research (NIOZ), Yerseke, Netherlands, ${ }^{12}$ Department of Oceanography, Istituto Nazionale di Oceanografia e di Geofisica Sperimentale - OGS, Sgonico, Italy, ${ }^{13}$ Nereis Bioengineering, Llanwrda, United Kingdom, ${ }^{14}$ Norwegian Institute for Water Research (NIVA), Oslo, Norway, ${ }^{15}$ P. P. Shirshov Institute of Oceanology RAS, Moscow, Russia

The benthic environment is a crucial component of marine systems in the provision of ecosystem services, sustaining biodiversity and in climate regulation, and therefore important to human society. With the contemporary increase in computational power, model resolution and technological improvements in quality and quantity of benthic data, it is necessary to ensure that benthic systems are appropriately represented in coupled benthic-pelagic biogeochemical and ecological modelling studies. In this paper we focus on five topical challenges related to various aspects of modelling benthic environments: organic matter reactivity, dynamics of benthic-pelagic boundary layer, microphytobenthos, biological transport and small-scale heterogeneity, and impacts of episodic events. We discuss current gaps in their understanding and indicate plausible ways ahead. Further, we propose a three-pronged approach for the advancement of benthic and benthic-pelagic modelling, essential for improved understanding, management and prediction of the marine environment. This includes: $(A)$ development of a traceable and hierarchical framework for benthic-pelagic models, which will facilitate integration among models, reduce risk of bias, and clarify model limitations; (B) extended cross-disciplinary approach to promote effective collaboration between modelling and empirical scientists of various backgrounds and better involvement of stakeholders and end-users; (C) a common vocabulary for terminology used in benthic modelling, to promote model development and integration, and also to enhance mutual understanding.

Keywords: benthic modelling, sediment biogeochemistry, benthic-pelagic coupling, organic matter, recovery, spatial heterogeneity, microphytobenthos, bottom boundary layer 


\section{INTRODUCTION}

The benthic environment is a key component of marine systems: it represents the transfer zone between the biosphere and geosphere; it provides a habitat for organisms from all domains of life; and it modulates biogeochemical cycles of carbon, macroand micronutrients and trace elements. The benthos can be a source of material for the water column (e.g., releasing nutrients from mineralisation of organic matter) as well as a temporary or permanent sink (e.g., C-sequestration). Furthermore, from an ecological point of view, benthic systems play a major role in sustaining biodiversity both directly, with large number of species/orders/phyla, and indirectly, by providing a large number of diverse habitats via ecosystem engineering (Meysman et al., 2006).

Despite this, benthic systems are generally under-represented in marine ecosystem models, in both regional and global applications, and are mostly present as a simple closure term for mass conservation (Soetaert et al., 2000; Hülse et al., 2017). Historically, the parallel development of marine hydrodynamic models and pelagic biogeochemical or plankton models, starting with NPZ formulations (Steele and Henderson, 1981; Fasham et al., 1990), coalesced because their spatial and temporal scales were compatible. Benthic modelling, however, often started from a different conceptual basis such as biodiversity (Hughes, 1984) or diagenesis (Berner, 1980; Boudreau, 1997; Paraska et al., 2014) considering different spatial and temporal scales, sometimes different currencies, and different mechanisms of particle and solute transport, which in sediments is enhanced by biological activity. Consequently, this divergence in development has led to marked differences in the characteristics of the two modelling approaches. Benthic models tend to be applied over smaller spatial scales (e.g., $\mathrm{mm}$ to $\mathrm{m}$ ), typically in $1 \mathrm{D}$ (vertical), and solved under steady-state assumptions, while pelagic models usually operate over larger ( $\mathrm{m}$ to $\mathrm{km}$ ) scales in $2 \mathrm{D}$ or $3 \mathrm{D}$, and are generally dynamic. Additionally, computational constraints have historically limited the ability to dynamically solve advective and diffusive transport in pore waters at large spatial scales; benthic data are relatively sparse and communication between the benthic and the pelagic scientific community has often been hindered by a lack of common vocabulary and objectives (Queirós et al., 2015). Nevertheless, fully coupled regional 3D pelagic-benthic models have been successfully developed and applied (Baretta et al., 1995; Wakelin et al., 2012) illustrating that there is no fundamental barrier between the two domains.

With the contemporary increase in computational power, model resolution and technology-led improvements in benthic data availability and synthesis, many of these constraints are now surmountable. Improved understanding of system complexity and feedbacks are providing renewed impetus for a holistic approach. For instance, understanding long-term evolution of the climate system requires a consideration of feedbacks from the sediments (Soetaert et al., 2000; Hülse et al., 2017); similarly, assessments of the impact of policies on marine environmental status can be worthless without accounting for the sediments that act as the memory of the system (Artioli et al., 2008; Soetaert and Middelburg, 2009). Conversely, investigating the evolution of benthic systems without considering pelagic dynamics may lead to imperfect answers.

Here, we present five priorities for further developing benthic process models that, due to their relevance and intrinsic interdisciplinary value, would ensure that the benthic system is given an appropriate consideration in coupled pelagic-benthic biogeochemical and ecological modelling studies (Figure 1).

\section{REACTIVITY OF ORGANIC MATERIAL}

One of the most important yet enigmatic aspects of benthic biogeochemistry is the reactivity of the particulate organic material (POM) degraded within the sediment (Berner, 1980). Constraining reactivity rates is crucial as it determines the sediment burial and recycling efficiencies (Martin and Bender, 1988; Soetaert et al., 1996), which allow the quantification of benthic-pelagic solute fluxes and, ultimately, feedbacks on ocean chemistry. Organic matter reactivity controls the nature and magnitude of the electron acceptor sinks from the water column: close to the sediment surface underlying oxic waters POM will be mainly respired aerobically and through denitrification, whereas deeper within the sediment it will mainly be mineralised through anaerobic pathways such as sulphate-reduction and methanogenesis (Regnier et al., 2011).

Parameterisation of POM reactivity in models requires information on external (environmental) and internal (intrinsic to the POM composition) regulating factors. The role each of these factors play in POM mineralisation is still very poorly understood (Burdige, 2007; Arndt et al., 2013). Attempts have been made to mathematically describe the vertical distribution of degradation by compartmentalising POM into discrete reactive fractions. Yet, in areas of limited data availability different empirical relationships are used to constrain first-order rate constants as a function of a master variable such as the POM rain rate or the sedimentation rate (Toth and Lerman, 1977; Middelburg et al., 1997; Martin and Sayles, 2006; Thullner et al., 2009). However, their large-scale spatial patterns remain poorly known, and POM reactivity constants do not strongly correlate with these global master variables (Arndt et al., 2013). Nonetheless, POM rain rate may be used for predicting its reactivity when export production is reasonably well described (Dunne et al., 2007).

Less common approaches, in particular the power (Middelburg, 1989) and reactive continuum (Boudreau and Ruddick, 1991) models, assume a continuous distribution of reactive types that capture the full range of degradation time scales. They require less parameterisation than discrete models, but are difficult to apply to bioturbated sediments where age and reactivity of organic matter depend on the burial velocity and bioturbation rate (Meile and Van Cappellen, 2005). Parameterisation of the continuum model to bioturbated sediments better captures the degradation of labile material within the top few millimetres of sediment, and more accurately predicts the drawdown of oxygen and nitrate from the water column (Stolpovsky et al., 2015). Continuum models can also be used to define the reactivity of discrete POM fractions, which can 


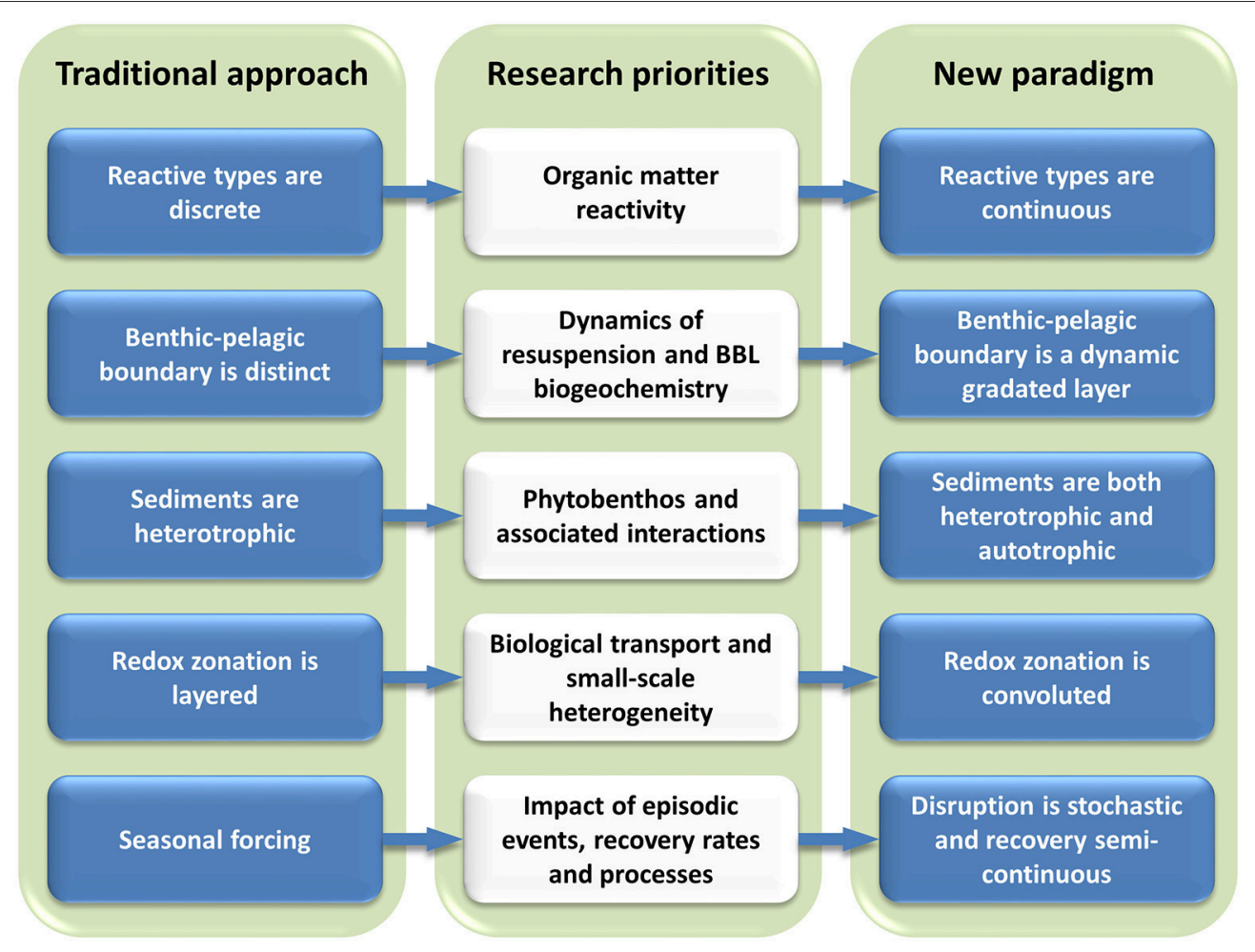

FIGURE 1 | Traditional view of benthic-pelagic coupling and approach to its representation in models (Left), the five cross-disciplinary research priorities that challenge this traditional approach (Middle), and lead to the new paradigm (Right), which is crucial for the improvement of biogeochemical and ecological modelling studies of the marine environment.

then be coupled to the total rain of POM to the seafloor (Dale et al., 2015). However, such approaches are generally not well suited to coastal areas and seas where seasonality is especially important. A better understanding of the spatiotemporal variability of lifetime and composition of POM is crucial for an improved representation of the benthic-pelagic coupling at regional to global scales.

\section{THE CONTINUUM OF THE BENTHIC-PELAGIC BOUNDARY LAYER}

The benthic-pelagic boundary is often simplistically regarded as a discontinuity, the interface between a completely fluid, dynamic water column and a rigid, porous benthic system. The reality is a spatially and temporally varying dynamic bottom boundary layer (BBL), characterised by strong physico-chemical gradients. While the importance of this layer on the mediation and transformation of biogeochemical fluxes, the transfer of organic material and sustaining heterogeneity of benthic habitats has been widely recognised, many uncertainties remain (Boudreau and Jorgensen, 2001).

The benthic-pelagic transition is often blurred by the presence of easily resuspendable unconsolidated "fluff" and fluid muds, which can form layers extending from a few centimetres to several meters into the pelagic. The flocculent "fluff" usually consists of newly deposited POM, and can sustain rich microbial communities, also being a valuable food resource for benthic fauna (Laima et al., 2002). Fluid muds containing high concentrations of fine particular material are distinctive for the major delta-forming rivers, but also common in other coastal systems (McAnally et al., 2007). They may be subject to repetitive redox successions and mixing of refractory riverine material with more labile estuarine organic matter (Aller, 1998; Aller and Blair, 2006). To better account for the fate of organic material within the BBL, better knowledge of its composition, degradation and consumption as well as transport dynamics, is necessary. Supporting this development requires data collected with equipment that preserves the sediment-water interface structure.

At the opposite side of benthic-pelagic continuum, properties of pore water in non-cohesive sandy sediments are similar to the water column due to enhanced exchange of solutes, dominated by advective rather than diffusive transport driven by physical forcing, and enhanced by burrowing organisms (Huettel and Webster, 2001; Volkenborn et al., 2012). This affects redox structure, biological activity and ultimately the potential for carbon sequestration (Reckhardt et al., 2015). Better characterisation of sediment types and their regional distribution is necessary to more accurately quantify material fluxes and transformations in coupled models (Almroth Rosell, 2011).

Representation of a continuous benthic-pelagic interface in models requires adequate resolution: layers of few millimetres in thickness can be important for the bulk of 
biogeochemical transformations. A compromise usually lies between implementing high vertical resolution within the BBL and consolidated sediments (Yakushev et al., 2017) or choosing implicit parameterisations of vertical distributions (Ruardij and Van Raaphorst, 1995). To account for smooth benthic-pelagic transition in models, decreasing turbulent diffusivity with depth can be prescribed in the BBL, or potentially parameterised based on gradients of organic matter concentration and properties.

\section{MICROPHYTOBENTHIC PRIMARY PRODUCTION}

A large area of the coastal sediment receives enough light to support photosynthesis and sustain benthic primary production (Gattuso et al., 2006), whether seagrasses, macroalgae or microphytobenthos (MPB), which are generally not yet considered in holistic model systems. For example the MPB-typically dominated by pennate diatoms-can be biogeochemically significant, particularly in oligotrophic settings, supported by nutrients regenerated during benthic mineralisation (Glud et al., 2009b). Their diel rhythm of respiration and photosynthesis has implications for benthic redox conditions and affects the availability of oxygen and labile organic material in the upper centimetres of the sediment (Cook et al., 2007). This dynamic directly affects key processes in the nitrogen cycle (nitrification, denitrification, DNRA), the redox cycling of metal-oxides and metal-sulphides and thereby the mobility of metals, trace-metals, phosphorus, sulphur, and pollutants (Risgaard-Petersen et al., 1993; Fenchel and Glud, 2000; Dalsgaard, 2003). Recent investigations suggest that MPB metabolism also may directly influence nitrogen turnover through DNRA and intracellular storage of nitrate (Kamp et al., 2011). Furthermore, extensive production of exopolymeric substances by MPB can affect the permeability and erosion thresholds of sediments (Hanlon et al., 2006; Pierre et al., 2014). However, only a few theoretical models on element cycling, food web structure or biogeochemistry in the coastal zone illustrate the potential of MPB (Blackford, 2002; Baird et al., 2016). Inclusion of MPB in biogeochemical and trophic models requires high quality data on distribution and processes mediated by MPB. New field approaches for mapping biomass (Glud et al., 2002; Kazemipour et al., 2012), trophic coupling (Evrard et al., 2008; Oakes et al., 2012) and performance of MPB (Berg et al., 2013; Attard et al., 2014) may better facilitate model parameterisation, although basic understanding of in situ growth and grazing on MPB communities is still rudimentary. However, to fully appreciate the importance of MPB, field efforts have to be closely linked to investigations on physiology, metabolism and behaviour of MPB-dominated communities by, for instance, taking advantage of new imaging approaches (Grunwald and Kühl, 2004; Ralph et al., 2005; Hancke et al., 2014).

\section{BIOLOGICAL TRANSPORT AND SMALL-SCALE HETEROGENEITY}

Benthic systems are characterised by spatial heterogeneity at all scales, making sediments a complex mosaic of redox conditions and habitat niches, often not sufficiently represented by average rates or attributes (Glud et al., 2009a). Without understanding this variability, benthic systems may exhibit apparently paradoxical behaviour. For instance, nitrification in deep nominally anoxic sediment layers (Satoh et al., 2007), occurring as a consequence of burrowing fauna pumping oxygenated waters into the deeper sediment, locally modifying redox conditions (Wenzhöfer and Glud, 2004; Volkenborn et al., 2010). Biogeochemical models mostly consider bio-irrigation (biological enhancement of solute transfer) as a factor enhancing the diffusion coefficient (Blackford, 1997; Reed et al., 2011), resulting in a thicker oxic layer near the sediment surface. However, the transport of oxygen (and other solutes) will likely not occur homogenously, rather being concentrated along the network of burrows (Glud et al., 2016), which become an extension of the oxic-anoxic interface. It has been shown that burrowing activity of benthic macrofauna can lead to as much as $400 \%$ increase in denitrification rates (Gilbert et al., 1998; Webb and Eyre, 2004), mostly due to the high rates of nitrification occurring within the burrows (Howe et al., 2004). Burrows thus offer an ideal environment for diverse microbial communities to work very closely and efficiently: indeed, genetic analysis has shown that in-burrow bacterial communities are more similar to the surface sediment community than the ambient sediment community at similar depth (Satoh et al., 2007; Laverock et al., 2010). Conversely, anaerobic microniches may be formed in surface aerobic sediments when the consumption rate due to the mineralisation of POM by bacteria is higher than the oxygen diffusion into the particle. Under these conditions, anaerobic processes such as sulphate reduction and denitrification (Jørgensen, 1977; Lehto et al., 2014) may occur at the sediment surface.

Recently, sulphide oxidation has been observed even within anoxic sediments, at the expense of the free oxygen in the distant oxic layer, thanks to the presence of filamentous cable bacteria that physically connect the two layers and act as micro-cables transferring electrons (Nielsen et al., 2010; Pfeffer et al., 2012). In a seasonally hypoxic basin in the North Sea, cable bacteria are very abundant and active during winter when they build a large buffer of iron (hydro-)oxides before the onset of summer hypoxia that is able to prevent the formation of euxinic toxic waters by chemically oxidising the sulphides formed during summer (Seitaj et al., 2015). Sharp discontinuities in the redox structure of the benthic environment are rarely represented in models despite their potential significance. Explicit representation of these processes would require a significant increase in the vertical resolution of benthic models, which may be incompatible with operational modelling. In order to properly upscale these processes, detailed models implemented at a small scale, or a sub-grid scale approach could be used to derive optimal parameterisations.

\section{EPISODIC EVENTS AND RECOVERY}

Seasonal variability is an important driver of benthic-pelagic coupling in the marine environment (Martens, 1976; Aller, 1994). While it is relatively well described in current models, the role of episodic events has been long neglected because of the lack 
of observations and their unpredictability (Durrieu de Madron et al., 2011). Along the continental slope, earthquakes may generate landslides that affect deposition and, consequently, the benthic ecosystem (Oguri et al., 2013). Other events such as storms and river floods have been shown to dominate particle transport in key areas of the coastal zone which implies a large effect on community structuration and biogeochemical function. In the North-Western Mediterranean, for example, the Rhône River shows very large floods that represent $70-80 \%$ of the annual particulate delivery (Antonelli et al., 2008) including POM. These very large deposition rates generate disturbances of the benthic communities and their functions, and recovery is often terminated by another event (Cathalot et al., 2010). At the same time, river floods deliver large amounts of nutrients that induce phytoplankton blooms which feed the pelagic and benthic biota (Auger et al., 2011). Waves and storm-induced currents can resuspend fine particulates from centimetres in the sediment (Toussaint et al., 2014; Bourrin et al., 2015) and transport them away from the nearshore coastal zone, thus feeding deeper benthic communities spread on the shelf and deep slope (Jahnke et al., 1990). Export from the shelf to the deep-sea is also dominated by intense events (Sanchez-Vidal et al., 2008) through cascading or downwelling in canyons. In the North-Western Mediterranean, cascading arises from a peak of cold winds which generate cold and dense waters on the shelf that are transported to the shelf break and sink, whereas downwelling events are linked to storms and cyclonic circulation. Both these phenomena contribute to major export of particles (Ulses et al., 2008) which impoverish the shelf and have profound impacts on the deep-sea ecosystem (Sanchez-Vidal et al., 2012) including beneficial feeding of the shrimp populations (Canals et al., 2009). Post-disturbance recovery dynamics of benthic systems will differ depending on nature of disturbance: hypoxia (Rosenberg et al., 2002), benthic trawling (Collie et al., 2000), dredge dumping (Bolam et al., 2006) or deep sea mining (Jones et al., 2017) will have different impacts and dynamics of recovery. One of the modelling challenges is the representation of lateral recolonization in benthic communities (Dittmann et al., 1999; Fowler, 2002), since microbial functions such as denitrification only return fully after recovery of deep-digging fauna (Van Colen et al., 2012). Modelling the impacts of intense events on benthic systems requires consideration of both the physical reorganisation of the sediments and the associated response of flora and fauna. Synthesis of current understanding of effects of these events on organisms' physiology and ecology will facilitate better parameterisation of their impacts.

\section{CONCLUSIONS}

Benthic environments are a crucial component in the functioning of marine systems and their services, particularly under the increasing pressure from anthropogenic activities and climate change. Therefore, development and application of numerical models that integrate our understanding of benthic systems is essential. However, benthic models often require complex, specific structures and scales, very different from faster-developing pelagic counterparts. In this paper, we have discussed some topical challenges related to different aspects of benthic environments, gaps in their understanding, and research priorities that will lead to tackling these gaps using a modelling approach (Figure 1).

We believe that these challenges can be addressed properly with a different and broader approach than has been used in the past, one that maximises the utility of benthic modelling within a whole systems approach. In particular:

- Building on (Soetaert et al., 2000) approach, a framework of traceable and hierarchical complexity for benthic-pelagic models should be developed. Benthic systems exert different effects and functions depending on the spatial and temporal scale being considered. Depending on the scientific question, some aspects can be neglected, others can be simplified. The function of the framework would be to assure that these choices are fully transparent both to scientists and end-users. This approach will facilitate integration among models, reduce risk of bias, and clarify any model limitations.

- A cross-disciplinary approach is needed: the complexity of benthic systems requires an integrated approach toward research, which necessitates effective communication and collaboration between modelling and empirical scientists of various backgrounds, involving stakeholders and end-users (Queirós et al., 2015). This approach has to be fully integrated rather than sequential or in parallel, including the design of the conceptual framework of the modelling and experimental approach.

- A common vocabulary for terminology used in benthic modelling community needs to be developed. With many strains and flavours of benthic models developed to date, an effective interdisciplinary dialogue requires a common language not only to promote model development and integration, but also to enhance mutual understanding and avoid ambiguity.

These three pillars form the foundation for a robust advancement in multi-disciplinary collaborations in benthic and benthicpelagic research necessary to better understand, manage and predict the marine environment.

\section{AUTHOR CONTRIBUTIONS}

All authors contributed to EuroMarine workshop "A multidisciplinary consortium approach for advancement of conceptual frameworks, modelling and experimental approaches to benthicpelagic coupling" held at Plymouth Marine Laboratory on May $18-19,2015$, and to consequent discussions leading to this contribution.

\section{FUNDING}

This publication was supported by the EuroMarine Network (https://www.euromarinenetwork.eu). GL, YA, and JB were supported by the Marine Ecosystems Research Programme (NE/L003066/1) and UK Shelf Seas Biogeochemistry programme 
(NE/K001876/1), both funded by the UK Natural Environment Research Council (NERC) and the Department for Environment, Food and Rural Affairs (Defra), as well as NERC National Capability in Marine Modelling. RG was supported by the European Research Council (HADES, grant no. 669947). AQ was funded under the Marine Ecosystems Research Programme (NERC and Defra, [NE/L003279/1]). AD was supported by the Sonderforschungsbereich 754 "Climate - Biogeochemistry Interactions in the Tropical Ocean" (www.sfb754.de) from the Deutsche Forschungsgemeinschaft. EA-R was supported by the

\section{REFERENCES}

Aller, R. C. (1994). The sedimentary Mn cycle in Long Island Sound: its role as intermediate oxidant and the influence of bioturbation, O2, and Corg flux on diagenetic reaction balances. J. Mar. Res. 52, 259-295. doi: 10.1357/0022240943077091

Aller, R. C. (1998). Mobile deltaic and continental shelf muds as suboxic, fluidized bed reactors. Mar. Chem. 61, 143-155. doi: 10.1016/S0304-4203(98)00024-3

Aller, R. C., and Blair, N. E. (2006). Carbon remineralization in the AmazonGuianas tropical mobile mudbelt: a sedimentary incinerator. Cont. Shelf Res. 26, 2241-2259. doi: 10.1016/j.csr.2006.07.016

Almroth Rosell, E. (2011). Influence of Resuspension on Sediment-Water Solute Exchange and Particle Transport in Marine Environments. Ph.D., University of Gothenburg.

Antonelli, C., Eyrolle, F., Rolland, B., Provansal, M., and Sabatier, F. (2008). Suspended sediment and 137 Cs fluxes during the exceptional December 2003 flood in the Rhone River, southeast France. Geomorphology 95, 350-360. doi: 10.1016/j.geomorph.2007.06.007

Arndt, S., Jørgensen, B. B., LaRowe, D. E., Middelburg, J., Pancost, R., and Regnier, P. (2013). Quantifying the degradation of organic matter in marine sediments: a review and synthesis. Earth Sci. Rev. 123, 53-86. doi: 10.1016/j.earscirev.2013.02.008

Artioli, Y., Friedrich, J., Gilbert, A. J., McQuatters-Gollop, A., Mee, L. D., Vermaat, J. E., et al. (2008). Nutrient budgets for European seas: a measure of the effectiveness of nutrient reduction policies. Mar. Pollut. Bull. 56, 1609-1617. doi: 10.1016/j.marpolbul.2008.05.027

Attard, K. M., Glud, R. N., McGinnis, D. F., and Rysgaard, S. (2014). Seasonal rates of benthic primary production in a Greenland fjord measured by aquatic eddy correlation. Limnol. Oceanogr. 59, 1555-1569. doi: 10.4319/lo.2014.59.5.1555

Auger, P., Diaz, F., Ulses, C., Estournel, C., Neveux, J., Joux, F., et al. (2011). Functioning of the planktonic ecosystem on the Gulf of Lions shelf (NW Mediterranean) during spring and its impact on the carbon deposition: a field data and 3-D modelling combined approach. Biogeosciences 8, 3231-3261. doi: 10.5194/bg-8-3231-2011

Baird, M. E., Cherukuru, N., Jones, E., Margvelashvili, N., Mongin, M., Oubelkheir, K., et al. (2016). Remote-sensing reflectance and true colour produced by a coupled hydrodynamic, optical, sediment, biogeochemical model of the Great Barrier Reef, Australia: comparison with satellite data. Environ. Model. Softw. 78(Suppl. C), 79-96. doi: 10.1016/j.envsoft.2015.11.025

Baretta, J., Ebenhöh, W., and Ruardij, P. (1995). The European regional seas ecosystem model, a complex marine ecosystem model. Netherlands J. Sea Res. 33, 233-246. doi: 10.1016/0077-7579(95)90047-0

Berg, P., Long, M. H., Huettel, M., Rheuban, J. E., McGlathery, K. J., Howarth, R. W., et al. (2013). Eddy correlation measurements of oxygen fluxes in permeable sediments exposed to varying current flow and light. Limnol. Oceanogr. 58, 1329-1343. doi: 10.4319/lo.2013.58.4.1329

Berner, R. A. (1980). Early Diagenesis: A Theoretical Approach. Princeton, NJ: Princeton University Press.

Blackford, J. (2002). The influence of microphytobenthos on the Northern Adriatic ecosystem: a modelling study. Estuar. Coast. Shelf Sci. 55, 109-123. doi: $10.1006 /$ ecss.2001.0890

Blackford, J. C. (1997). An analysis of benthic biological dynamics in a North Sea ecosystem model. J. Sea Res. 38, 213-230. doi: 10.1016/S1385-1101(97)00044-0
BONUS COCOA project, funded by the Baltic Sea research and development programme (Art 185), funded jointly by the European Union's Seventh Framework Programme for research, technological development and demonstration and by the Swedish Research Council for Environment, Agricultural Sciences and Spatial Planning (FORMAS), grant no. 20132056. CR was funded by the Mistrals/Mermex programme and by the Amorad project ANR-11-RSNR-002 (Investissement d'Avenir). JM was supported by the Ministry of Education via the Netherlands Earth System Science Centre (NESSC).

Bolam, S. G., Rees, H. L., Somerfield, P., Smith, R., Clarke, K. R., Warwick, R., et al. (2006). Ecological consequences of dredged material disposal in the marine environment: a holistic assessment of activities around the England and Wales coastline. Mar. Pollut. Bull. 52, 415-426. doi: 10.1016/j.marpolbul.2005.09.028

Boudreau, B. P. (1997). Diagenetic Models and Their Implementation. Berlin: Springer.

Boudreau, B. P., and Jorgensen, B. B. (eds.). (2001). The Benthic Boundary Layer: Transport Processes and Biogeochemistry. Oxford. UK: Oxford University Press.

Boudreau, B. P., and Ruddick, B. R. (1991). On a reactive continuum representation of organic matter diagenesis. Am. J. Sci. 291, 507-538. doi: 10.2475/ajs.291.5.507

Bourrin, F., Many, G., de Madron, X. D., Martín, J., Puig, P., Houpert, L. et al. (2015). Glider monitoring of shelf suspended particle dynamics and transport during storm and flooding conditions. Cont. Shelf Res. 109, 135-149. doi: 10.1016/j.csr.2015.08.031

Burdige, D. J. (2007). Preservation of organic matter in marine sediments: controls, mechanisms, and an imbalance in sediment organic carbon budgets? Chem. Rev. 107, 467-485. doi: 10.1021/cr050347q

Canals, M., Danovaro, R., Heussner, S., Lykousis, V., Puig, P., Trincardi, F., et al. (2009). Cascades in Mediterranean submarine grand canyons. Oceanography 22, 26-43. doi: 10.5670/oceanog.2009.03

Cathalot, C., Rabouille, C., Pastor, L., Deflandre, B., Viollier, E., Buscail, R., et al. (2010). Temporal variability of carbon recycling in coastal sediments influenced by rivers: assessing the impact of flood inputs in the Rhône River prodelta Biogeosciences 7, 1187-1205. doi: 10.5194/bg-7-1187-2010

Collie, J. S., Hall, S. J., Kaiser, M. J., and Poiner, I. R. (2000). A quantitative analysis of fishing impacts on shelf-sea benthos. J. Anim. Ecol. 69, 785-798. doi: 10.1046/j.1365-2656.2000.00434.x

Cook, P. L., Veuger, B., Böer, S., and Middelburg, J. J. (2007). Effect of nutrient availability on carbon and nitrogen incorporation and flows through benthic algae and bacteria in near-shore sandy sediment. Aquat. Microb. Ecol. 49, 165-180. doi: 10.3354/ame01142

Dale, A. W., Sommer, S., Lomnitz, U., Montes, I., Treude, T., Liebetrau, V., et al. (2015). Organic carbon production, mineralization and preservation on the Peruvian margin. Biogeosciences 12, 1537-1559. doi: 10.5194/bg-12-1537-2015

Dalsgaard, T. (2003). Benthic primary production and nutrient cycling in sediments with benthic microalgae and transient accumulation of macroalgae. Limnol. Oceanogr. 48, 2138-2150. doi: 10.4319/lo.2003.48.6.2138

Dittmann, S., Günther, C.-P., and Schleier, U. (1999). "Recolonization of tidal flats after disturbance," in The Wadden Sea Ecosystem: Stability, Problems and Mechanisms, ed S. Dittmann (Berlin: Springer), 175-192.

Dunne, J. P., Sarmiento, J. L., and Gnanadesikan, A. (2007). A synthesis of global particle export from the surface ocean and cycling through the ocean interior and on the seafloor. Global Biogeochem. Cycles 21:GB4006 doi: 10.1029/2006GB002907

Durrieu de Madron, X., Guieu, C., Sempér,é, R., Conan, P., Cossa, D., D’Ortenzio, F., et al. (2011). Marine ecosystems' responses to climatic and anthropogenic forcings in the Mediterranean. Prog. Oceanogr. 91, 97-166. doi: 10.1016/j.pocean.2011.02.003

Evrard, V., Cook, P. L., Veuger, B., Huettel, M., and Middelburg, J. J. (2008). Tracing carbon and nitrogen incorporation and pathways in the microbial community of a photic subtidal sand. Aquat. Microb. Ecol. 53, 257-269. doi: $10.3354 / \mathrm{ame} 01248$ 
Fasham, M., Ducklow, H., and McKelvie, S. (1990). A nitrogen-based model of plankton dynamics in the oceanic mixed layer. J. Mar. Res. 48, 591-639. doi: $10.1357 / 002224090784984678$

Fenchel, T., and Glud, R. N. (2000). Benthic primary production and O2-CO2 dynamics in a shallow-water sediment: spatial and temporal heterogeneity. Ophelia 53, 159-171. doi: 10.1080/00785236.2000.10409446

Fowler, R. T. (2002). Relative importance of surface and subsurface movement on benthic community recovery in the Makaretu River, North Island, New Zealand. N. Z. J. Mar. Freshwater Res. 36, 459-469. doi: $10.1080 / 00288330.2002 .9517101$

Gattuso, J.-P., Gentili, B., Duarte, C. M., Kleypas, J., Middelburg, J. J., and Antoine, D. (2006). Light availability in the coastal ocean: impact on the distribution of benthic photosynthetic organisms and contribution to primary production. Biogeosci. Discuss. 3, 895-959. doi: 10.5194/bgd-3-895-2006

Gilbert, F., Stora, G., and Bonin, P. (1998). Influence of bioturbation on denitrification activity in Mediterranean coastal sediments: an in situ experimental approach. Mar. Ecol. Prog. Ser. 163, 99-107. doi: $10.3354 /$ meps 163099

Glud, R. N., Berg, P., Stahl, H., Hume, A., Larsen, M., Eyre, B. D., et al. (2016). Benthic carbon mineralization and nutrient turnover in a Scottish sea loch: an integrative in situ study. Aquat. Geochem. 22, 443-467. doi: 10.1007/s10498-016-9300-8

Glud, R. N., Kühl, M., Wenzhöfer, F., and Rysgaard, S. (2002). Benthic diatoms of a high Arctic fjord (Young Sound, NE Greenland): importance for ecosystem primary production. Mar. Ecol. Prog. Ser. 238, 15-29. doi: 10.3354/meps238015

Glud, R. N., Stahl, H., Berg, P., Wenzhöfer, F., Oguri, K., and Kitazato, H. (2009a). In situ microscale variation in distribution and consumption of 2: a case study from a deep ocean margin sediment (Sagami Bay, Japan). Limnol. Oceanogr. 54, 1-12. doi: 10.4319/lo.2009.54.1.0001

Glud, R. N., Woelfel, J., Karsten, U., Kühl, M., and Rysgaard, S. (2009b). Benthic microalgal production in the Arctic: applied methods and status of the current database. Bot. Mar. 52, 559-571. doi: 10.1515/BOT.2009.074

Grunwald, B., and Kühl, M. (2004). A system for imaging variable chlorophyll fluorescence of aquatic phototrophs. Ophelia 58, 79-89. doi: 10.1080/00785326.2004.10410215

Hancke, K., Sorell, B. K., Lund-Hansen, L. C., Larsen, M., Hancke, T., and Glud, R. N. (2014). Effects of temperature and irradiance on a benthic microalgal community: a combined two-dimensional oxygen and fluorescence imaging approach. Limnol. Oceanogr. 59, 1599-1611. doi: 10.4319/lo.2014.59. 5.1599

Hanlon, A., Bellinger, B., Haynes, K., Xiao, G., Hofmann, T., Gretz, M., et al. (2006). Dynamics of extracellular polymeric substance (EPS) production and loss in an estuarine, diatom-dominated, microalgal biofilm over a tidal emersionimmersion period. Limnol. Oceanogr. 51, 79-93. doi: 10.4319/lo.2006.51.1.0079

Howe, R. L., Rees, A. P., and Widdicombe, S. (2004). The impact of two species of bioturbating shrimp (Callianassa subterranea and Upogebia deltaura) on sediment denitrification. J. Mar. Biol. Assoc. U.K. 84, 629-632. doi: $10.1017 /$ S002531540400966Xh

Huettel, M., and Webster, I. T. (2001). "Porewater flow in permeable sediments," in The Benthic Boundary Layer, eds B. P. Boudreau and B. B. Jørgensen (New York, NY: Oxford University Press), 144-179.

Hughes, R. G. (1984). A model of the structure and dynamics of benthic marine invertebrate communities. Mar. Ecol. Progr. Ser. 15, 1-11. doi: 10.3354/meps015001

Hülse, D., Arndt, S., Wilson, J. D., Munhoven, G., and Ridgwell, A. (2017). Understanding the causes and consequences of past marine carbon cycling variability through models. Earth Sci. Rev. 171, 349-382. doi: 10.1016/j.earscirev.2017.06.004

Jahnke, R. A., Reimers, C. E., and Craven, D. B. (1990). Intensification of recycling of organic matter at the sea floor near ocean margins. Nature 348, 50-54. doi: $10.1038 / 348050 \mathrm{a} 0$

Jones, D. O., Kaiser, S., Sweetman, A. K., Smith, C. R., Menot, L., Vink, A., et al. (2017). Biological responses to disturbance from simulated deep-sea polymetallic nodule mining. PLoS ONE 12:e0171750. doi: 10.1371/journal.pone. 0171750

Jørgensen, B. B. (1977). Bacterial sulfate reduction within reduced microniches of oxidized marine sediments. Mar. Biol. 41, 7-17. doi: 10.1007/BF00390576
Kamp, A., de Beer, D., Nitsch, J. L., Lavik, G., and Stief, P. (2011). Diatoms respire nitrate to survive dark and anoxic conditions. Proc. Natl. Acad. Sci. U.S.A. 108, 5649-5654. doi: 10.1073/pnas.1015744108

Kazemipour, F., Launeau, P., and Méléder, V. (2012). Microphytobenthos biomass mapping using the optical model of diatom biofilms: application to hyperspectral images of Bourgneuf Bay. Remote Sens. Environ. 127, 1-13. doi: 10.1016/j.rse.2012.08.016

Laima, M., Maksymowska-Brossard, D., Sauriau, P.-G., Richard, P., Girard, M., Gouleau, D., et al. (2002). Fluff deposition on intertidal sediments: effects on benthic biota, ammonium fluxes and nitrification rates. Biogeochemistry 61, 115-133. doi: 10.1023/A:1020264414924

Laverock, B., Smith, C. J., Tait, K., Osborn, A. M., Widdicombe, S., and Gilbert, J. A. (2010). Bioturbating shrimp alter the structure and diversity of bacterial communities in coastal marine sediments. ISME J. 4, 1531-1544. doi: 10.1038 /ismej.2010.86

Lehto, N., Glud, R. N., á Norð*i, G., Zhang, H., and Davison, W. (2014), Anoxic microniches in marine sediments induced by aggregate settlement: biogeochemical dynamics and implications. Biogeochemistry 119, 307-327. doi: 10.1007/s10533-014-9967-0

Martens, C. S. (1976). Control of methane sediment-water bubble transport by macroinfaunal irrigation in cape lookout bight, North Carolina. Science 192, 998-1000. doi: 10.1126/science.192.4243.998

Martin, W., and Bender, M. (1988). The variability of benthic fluxes and sedimentary remineralization rates in response to seasonally variable organic carbon rain rates in the deep sea; a modeling study. Am. J. Sci. 288, 561-574. doi: $10.2475 /$ ajs.288.6.561

Martin, W., and Sayles, F. (2006). Organic matter oxidation in deep-sea sediments: distribution in the sediment column and implications for calcite dissolution. Deep Sea Res. Part II Top. Stud. Oceanogr. 53, 771-792. doi: 10.1016/j.dsr2.2006.01.017

McAnally, W. H., Friedrichs, C., Hamilton, D., Hayter, E., Shrestha, P., Rodriguez, H., et al. (2007). Management of fluid mud in estuaries, bays, and lakes. I: present state of understanding on character and behavior. J. Hydr. Eng. 133, 9-22. doi: 10.1061/(ASCE)0733-9429(2007)133:1(9)

Meile, C., and Van Cappellen, P. (2005). Particle age distributions and O2 exposure times: timescales in bioturbated sediments. Global Biogeochem. Cycles 19:GB3013. doi: 10.1029/2004GB002371

Meysman, F. J., Middelburg, J. J., and Heip, C. H. (2006). Bioturbation: a fresh look at Darwin's last idea. Trends Ecol. Evol. 21, 688-695. doi: 10.1016/j.tree.2006.08.002

Middelburg, J. J. (1989). A simple rate model for organic matter decomposition in marine sediments. Geochim. Cosmochim. Acta 53, 1577-1581. doi: 10.1016/0016-7037(89)90239-1

Middelburg, J. J., Soetaert, K., and Herman, P. M. (1997). Empirical relationships for use in global diagenetic models. Deep Sea Res. Part I Oceanogr. Res. Pap. 44, 327-344. doi: 10.1016/S0967-0637(96)00101-X

Nielsen, L. P., Risgaard-Petersen, N., Fossing, H., Christensen, P. B., and Sayama, M. (2010). Electric currents couple spatially separated biogeochemical processes in marine sediment. Nature 463, 1071-1074. doi: $10.1038 /$ nature 08790

Oakes, J. M., Eyre, B. D., and Middelburg, J. J. (2012). Transformation and fate of microphytobenthos carbon in subtropical shallow subtidal sands: a 13C-labeling study. Limnol. Oceanogr. 57, 1846-1856. doi: 10.4319/lo.2012.57.6.1846

Oguri, K., Kawamura, K., Sakaguchi, A., Toyofuku, T., Kasaya, T., Murayama, M., et al. (2013). Hadal disturbance in the Japan Trench induced by the 2011 Tohoku-Oki Earthquake 3:1915. doi: 10.1038/srep01915

Paraska, D. W., Hipsey, M. R., and Salmon, S. U. (2014). Sediment diagenesis models: review of approaches, challenges and opportunities. Environ. Model. Softw. 61, 297-325. doi: 10.1016/j.envsoft.2014.05.011

Pfeffer, C., Larsen, S., Song, J., Dong, M., Besenbacher, F., Meyer, R. L., et al. (2012). Filamentous bacteria transport electrons over centimetre distances. Nature 491, 218-221. doi: 10.1038/nature11586

Pierre, G., Zhao, J.-M., Orvain, F., Dupuy, C., Klein, G. L., Graber, M., et al. (2014). Seasonal dynamics of extracellular polymeric substances (EPS) in surface sediments of a diatom-dominated intertidal mudflat (MarennesOléron, France). J. Sea Res. 92, 26-35. doi: 10.1016/j.seares.2013.07.018 
Queirós, A. M., Bruggeman, J., Stephens, N., Artioli, Y., Butenschön, M., Blackford, J. C., et al. (2015). Placing biodiversity in ecosystem models without getting lost in translation. J. Sea Res. 98, 83-90. doi: 10.1016/j.seares.2014.10.004

Ralph, P. J., Schreiber, U., Gademann, R., Kühl, M., and Larkum, A. W. (2005). Coral photobiology studied with a new imaging pulse amplitude modulated fluorometer1. J. Phycol. 41, 335-342. doi: 10.1111/j.1529-8817.2005. 04034.x

Reckhardt, A., Beck, M., Seidel, M., Riedel, T., Wehrmann, A., Bartholomä, A., et al. (2015). Carbon, nutrient and trace metal cycling in sandy sediments: a comparison of high-energy beaches and backbarrier tidal flats. Estuar. Coast. Shelf Sci. 159, 1-14. doi: 10.1016/j.ecss.2015.03.025

Reed, D. C., Slomp, C. P., and Gustafsson, B. G. (2011). Sedimentary phosphorus dynamics and the evolution of bottom-water hypoxia: a coupled benthicpelagic model of a coastal system. Limnol. Oceanogr. 56, 1075-1092. doi: 10.4319/lo.2011.56.3.1075

Regnier, P., Dale, A. W., Arndt, S., LaRowe, D., Mogollón, J., and Van Cappellen, P. (2011). Quantitative analysis of anaerobic oxidation of methane (AOM) in marine sediments: a modeling perspective. Earth Sci. Rev. 106, 105-130. doi: 10.1016/j.earscirev.2011.01.002

Risgaard-Petersen, N., Rysgaard, S., and Revsbech, N. P. (1993). A sensitive assay for determination of ${ }^{14} \mathrm{~N} /{ }^{15} \mathrm{~N}$ isotope distribution in $\mathrm{NO}_{3}^{-}$. J. Microbiol. Methods 17, 155-164. doi: 10.1016/0167-7012(93)90009-7

Rosenberg, R., Agrenius, S., Hellman, B., Nilsson, H. C., and Norling, K. (2002). Recovery of marine benthic habitats and fauna in a Swedish fjord following improved oxygen conditions. Mar. Ecol. Prog. Ser. 234, 43-53. doi: 10.3354/meps 234043

Ruardij, P., and Van Raaphorst, W. (1995). Benthic nutrient regeneration in the ERSEM ecosystem model of the North Sea. Netherlands J. Sea Res. 33, 453-483. doi: 10.1016/0077-7579(95)90057-8

Sanchez-Vidal, A., Pasqual, C., Kerhervé, P., Calafat, A., Heussner, S., Palanques, A., et al. (2008). Impact of dense shelf water cascading on the transfer of organic matter to the deep western Mediterranean basin. Geophys. Res. Lett. 35:L0560. doi: 10.1029/2007GL032825

Sanchez-Vidal, A., Canals, M., Calafat, A. M., Lastras, G., Pedrosa-Pàmies, R., Menéndez, M., et al. (2012). Impacts on the deep-sea ecosystem by a severe coastal storm. PLoS ONE 7:e30395. doi: 10.1371/journal.pone.0030395

Satoh, H., Nakamura, Y., and Okabe, S. (2007). Influences of infaunal burrows on the community structure and activity of ammonia-oxidizing bacteria in intertidal sediments. Appl. Environ. Microbiol. 73, 1341-1348. doi: 10.1128/AEM.02073-06

Seitaj, D., Schauer, R., Sulu-Gambari, F., Hidalgo-Martinez, S., Malkin, S. Y., Burdorf, L. D. W., et al. (2015). Cable bacteria generate a firewall against euxinia in seasonally hypoxic basins. Proc. Natl. Acad. Sci. U.S.A. 112, 13278-13283. doi: 10.1073/pnas.1510152112

Soetaert, K., Herman, P. M., and Middelburg, J. J. (1996). Dynamic response of deep-sea sediments to seasonal variations: a model. Limnol. Oceanogr. 41, 1651-1668. doi: 10.4319/lo.1996.41.8.1651

Soetaert, K., and Middelburg, J. J. (2009). Modeling eutrophication and oligotrophication of shallow-water marine systems: the importance of sediments under stratified and well-mixed conditions. Hydrobiologia 629, 239-254. doi: 10.1007/s10750-009-9777-x

Soetaert, K., Middelburg, J. J., Herman, P. M. J., and Buis, K. (2000). On the coupling of benthic and pelagic biogeochemical models. Earth Sci. Rev. 51, 173-201. doi: 10.1016/S0012-8252(00)00004-0

Steele, J., and Henderson, E. (1981). A simple plankton model. Am. Nat. 117, 676-691. doi: 10.1086/283752
Stolpovsky, K., Dale, A. W., and Wallmann, K. (2015). Toward a parameterization of global-scale organic carbon mineralization kinetics in surface marine sediments. Global Biogeochem. Cycles 29, 812-829. doi: 10.1002/2015GB005087

Thullner, M., Dale, A. W., and Regnier, P. (2009). Global-scale quantification of mineralization pathways in marine sediments: a reaction-transport modeling approach. Geochem. Geophys. Geosyst. 10:Q10012. doi: 10.1029/2009GC002484

Toth, D. J., and Lerman, A. (1977). Organic matter reactivity and sedimentation rates in the ocean. Am. J. Sci. 277, 465-485. doi: 10.2475/ajs.277.4.465

Toussaint, F., Rabouille, C., Cathalot, C., Bombled, B., Abchiche, A., Aouji, O., et al. (2014). A new device to follow temporal variations of oxygen demand in deltaic sediments: the LSCE benthic station. Limnol. Oceanogr. Methods 12, 729-741. doi: 10.4319/lom.2014.12.729

Ulses, C., Estournel, C., De Madron, X. D., and Palanques, A. (2008). Suspended sediment transport in the Gulf of Lions (NW Mediterranean): impact of extreme storms and floods. Cont. Shelf Res. 28, 2048-2070. doi: 10.1016/j.csr.2008.01.015

Van Colen, C., Rossi, F., Montserrat, F., Andersson, M. G., Gribsholt, B., Herman, P. M., et al. (2012). Organism-sediment interactions govern post-hypoxia recovery of ecosystem functioning. PLoS ONE 7:e49795. doi: 10.1371/journal.pone.0049795

Volkenborn, N., Polerecky, L., Wethey, D., DeWitt, T., and Woodin, S. (2012). Hydraulic activities by ghost shrimp Neotrypaea californiensis induce oxic- anoxic oscillations in sediments. Mar. Ecol. Prog. Ser. 455, 141-156. doi: $10.3354 /$ meps 09645

Volkenborn, N., Polerecky, L., Wethey, D., and Woodin, S. (2010). Oscillatory porewater bioadvection in marine sediments induced by hydraulic activities of Arenicola marina. Limnol. Oceanogr. 55, 1231-1247. doi: $10.4319 / 10.2010 .55 .3 .1231$

Wakelin, S., Holt, J., Blackford, J., Allen, J., Butenschön, M., and Artioli, Y. (2012). Modeling the carbon fluxes of the northwest European continental shelf: validation and budgets. J. Geophys. Res. Oceans 117:C05020. doi: 10.1029/2011JC007402

Webb, A. P., and Eyre, B. D. (2004). Effect of natural populations of burrowing thalassinidean shrimp on sediment irrigation, benthic metabolism, nutrient fluxes and denitrification. Mar. Ecol. Prog. Ser. 268, 205-220. doi: $10.3354 /$ meps 268205

Wenzhöfer, F., and Glud, R. N. (2004). Small-scale spatial and temporal variability in coastal benthic O2 dynamics: effects of fauna activity. Limnol. Oceanogr. 49, 1471-1481. doi: 10.4319/lo.2004.49.5.1471

Yakushev, E. V., Protsenko, E. A., Bruggeman, J., Wallhead, P., Pakhomova, S. V., Yakubov, S. K., et al. (2017). Bottom RedOx Model (BROM v.1.1): a coupled benthic-pelagic model for simulation of water and sediment biogeochemistry. Geosci. Model Dev. 10, 453-482. doi: 10.5194/gmd-10-453-2017

Conflict of Interest Statement: The authors declare that the research was conducted in the absence of any commercial or financial relationships that could be construed as a potential conflict of interest.

Copyright (C) 2018 Lessin, Artioli, Almroth-Rosell, Blackford, Dale, Glud, Middelburg, Pastres, Queirós, Rabouille, Regnier, Soetaert, Solidoro, Stephens and Yakushev. This is an open-access article distributed under the terms of the Creative Commons Attribution License (CC BY). The use, distribution or reproduction in other forums is permitted, provided the original author(s) and the copyright owner are credited and that the original publication in this journal is cited, in accordance with accepted academic practice. No use, distribution or reproduction is permitted which does not comply with these terms. 